\title{
Application of Adipose Derived Stem Cells for Treatment of Chronic Wounds
}

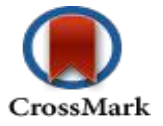

\author{
Rojin Kaviani, Reza B. Jalili*
}

Department of Surgery, Division of Plastic Surgery, University of British Columbia

"Corresponding author: Reza B. Jalili, MD, PhD, Assistant Professor, Division of Plastic Surgery, Department of Surgery, University of British Columbia, ICORD (International Collaboration on Repair Discoveries), Blusson Spinal Cord Centre, Rm 4530, 818 West 10 ${ }^{\text {th }}$ Ave. Vancouver, BC. V5Z 1M9 CANADA, Tel: 778232 4148; E-mail: rjalili@mail.ubc.ca

\begin{abstract}
Chronic wounds, such as pressure, venous, or diabetic ulcers, fail to progress through the orderly wound healing process. Due to limitations in current treatments, stem cell therapy has been considered as an alternative therapeutic approach to chronic wounds throughout the past decade. The use of adipose derived stem cells (ASCs) has been both a promising and practical treatment because of their relatively non-invasive extraction, high proliferation rate, and ability to differentiate into several mesodermal lineages. This mini-review provides a concise overview on the role of ASCs in wound healing and studies that have examined the application of ASCs in the treatment of chronic wounds.
\end{abstract}

Received date: October 11, 2015

Accepted date: February 4, 2016

Published date: February 10, 2016

Citation: Jalili, R.B., et al. Application of Adipose Derived Stem Cells for Treatment of Chronic Wounds. (2016) Invest Dermatol Venereol Res 2(1): 44- 51.

DOI: $10.15436 / 2381-0858.16 .011$

\section{Introduction}

A wound is an impairment of the normal anatomic structure and function of the skin that is restored through the orchestrated processes of wound healing ${ }^{[1]}$. Chronic wounds, such as pressure, venous, and diabetic foot ulcers fail to progress through the steps of wound healing in a timely fashion and instead remain in an inflammatory state ${ }^{[2]}$. Chronic wounds can have a severe impact on the quality of life of both the patients and their families. Patients can experience pain, loss of function and mobility, depression, anxiety, social isolation, financial burden, amputation, or even death ${ }^{[3,4]}$. In Canada, $26 \%$ of the patients in all healthcare institutions suffer from pressure ulcers ${ }^{[5]}$. Moreover, $0.8-1.3 \%$ of the general population and $2 \%$ of those older than 65 suffer from venous leg ulcers $^{[6]}$. A further $8-10 \%$ of the population suffer from diabetes, from which $15-25 \%$ will develop foot ulcers ${ }^{[7,8]}$. Foot and leg ulcers are the leading cause of amputations, resulting in $70 \%$ of non-traumatic lower extremity amputations ${ }^{[7,9]}$.

High prevalence of chronic wounds poses a major economic burden for healthcare systems ${ }^{[10]}$. For instance, in Ontario Canada, the average cost of an amputation is $\$ 40000$ to $\$ 74000$ per person and the direct cost of home-care and treatment for leg ulcers for one individual in a month is over $\$ 80,000$ and $\$ 21,000$, respectively ${ }^{[3,9]}$. Based on these data, patients pay an annual cost of $\$ 1.5$ million for home care, without including physician $\operatorname{costs}^{[3]}$. To put this into perspective, in Canada only more than $\$ 100$ million are spent on chronic wounds annually. The prevalence of chronic wounds is strongly related to age and underlying chronic conditions such as diabetes. Given the forecasted increase in both the average age of the population and prevalence of diabetes, the number of individuals at high risk for developing chronic wounds is expected to increase substantially ${ }^{[6,11]}$. Thereby, increasing the economic burden placed on the healthcare system.

Despite advancements in the understanding and prevention of chronic wounds, existing treatments for established wounds have been deemed unsatisfactory ${ }^{[12,13]}$. Over the past two decades, the uses of autologous stem cells have gained popularity as an alternative treatment. Unlike embryonic stem cells, autologous stem cells pose no ethical dilemmas and are also immunocompati$\mathrm{ble}^{[14]}$. This mini-review will explore the application of stem cells, specifically adipose-derived stem cells (ASCs), in the treatment of chronic wounds. 


\section{Wound Healing}

Wound healing involves spatially and temporally overlapping processes that encompass hemostasis, inflammation, cellular proliferation, and remodelling ${ }^{[15,16]}$. Immediately after injury, platelet aggregation occurs to prevent further blood loss. The resulting clotis made of various cell types that release chemotactic and other factors. These factors stimulate an inflammatory response in the first few days following injury ${ }^{[17]}$. Macrophages and neutrophils then infiltrate the wound area and clear debris. Another series of growth factors are released by macrophages that promote angiogenesis and stimulate the migration of fibroblasts, epithelial cells, and vascular endothelial cells into the wound ${ }^{[18]}$. This promotes tissue repair during the proliferative phase, once the inflammatory response subsides. The proliferative stage is characterized by the migration of several cell types into the wound that promote re-epithelization, angiogenesis, and collagen synthesis ${ }^{[19]}$. Fibroblasts and endothelial cells proliferate to form granulation tissue, extracellular matrix, and secrete a host of growth factors ${ }^{[20,21]}$. In the final stage of wound healing, remodelling of the extracellular matrix occurs. Collagen is deposited in an organized network in a process that can take years to finalize ${ }^{[19]}$. The final result is a matured scar with high tensile strength and optimized blood vessels and cells.

Chronic wounds fail to progress through these steps in a timely manner and remain in an inflammatory state ${ }^{[22]}$. This chronic inflammation causes further injury to the wound, which in turn results in greater inflammation. The resulting abnormal abundance of inflammatory cytokines generates a protease dominant microenvironment that affects the functionality of cells in the wound ${ }^{[23]}$. For instance, fibroblasts have been shown to exhibit lower migration capacity and response to growth factors in chronic wounds. Further, these wounds have a significantly delayed healing rate ${ }^{[24]}$. Ultimately, chronic wounds do not produce positive functional and anatomical outcomes ${ }^{[1]}$.

\section{Current Treatments}

Currently, treatment is mainly aimed at reducing inflammation. It is centered on the use of surgical debridement, antibiotics, dressings, offloading, and exogenous applications of cytokines and growth factors ${ }^{[25,26]}$. The latter treatment, which has the opportunity to heal chronic wounds, has been largely unsuccessful clinically due to the protease microenvironment and high $\operatorname{cost}^{t^{27,28]}}$. For venous ulcers, treatments involves elevation of the legs and application of external compression ${ }^{[29]}$. Yet, a systemic review of treatments for chronic venous ulcers identified a lack of high quality evidence supporting different types of wound therapy ${ }^{[12]}$. A similar review for pressure ulcers revealed that little evidence supported the usefulness of alternative treatments, such as specific supports surfaces, nutritional supplementations, or efficacy of different dressings, in comparison to the standard care for chronic wounds ${ }^{[13]}$.

In search for more effective treatments, researchers have examined the potential use of mesenchymal stem cells. By definition, stems cells have the ability to undergo self-renewal, differentiate into multiple lineages, and form terminally differentiated cells ${ }^{[30,31]}$. In order to be feasible for treatment, stem cells must meet multiple requirements: be available in abundant amounts of greater than a billion cells per individual, be harvested in minimally invasive procedures, differentiate into multiple lineages; and lastly, be safely transplanted in an autologous or allogeneic host ${ }^{[32]}$. Initially, research for alternative treatments focused on the use of mesenchymal stem cellsderived from bone marrow, referred to as bonemarrow mesenchymal stem cells (BMSCs). BMSCswere examined for its high proliferation rate and ability to differentiate into several mesodermal lineages ${ }^{[3,34]}$. Thus far, it has been used successfully to treat different types of wounds ${ }^{[35-37]}$. However, the invasive and difficult procedure forextraction of BMSCs has limitedits widespread clinical application. Not only is the extraction costly and highly invasive, but BMSCs alsohave a low incidence of about 1 per 105 cells in bone marrow ${ }^{[38]}$. The amount extracted can also vary per person due to effects of age, gender, or exposure to chemo/radiation therapy ${ }^{[39-42]}$.

Adult stem cells derived from adipose tissue are multipotent and have been studied as an attractive alternative to BMSCs. As adipose tissue is derived from mesenchyme, ASCs can differentiate into several mesenchymal lineages, such as, bone, adipose, muscle, cartilage, and also non-mesenchymal endothelial and neurogenic pathways ${ }^{[43-47]}$. It boasts higher incidence in tissue, ease of extraction, tissue abundance, and consequently, lower cost ${ }^{[48-50]}$. ASCs also proliferate at a faster rate and can be continuously cultured in vitro without a decrease in proliferation rate $^{[38,51]}$. ASCs have also been shown to produce different results in full thickness wounds ${ }^{[52]}$. For instance, it has been demonstrated that ASCs promoter greater formation of granulation tissue than BMSCs. Given these advantages over BMSCs, research is currently focusing on the use of ASCs in wound healing.

\section{Adipose-derived stem cells (ASCs)}

The isolation of ASCs that was first described by Rodbelland Jones ${ }^{[53-55]}$ in the1960'shas largely remained the same today ${ }^{[32]}$. Fat tissue harvested from fat pads of rodentswere minced and digested in collagenase and centrifuged. The free-floating fat cells in the supernatant were removed and the stromal vascular fraction (SVF) that remained formed a pellet.SVF isolated from this procedure was first identified to contain mast cells, macrophages, connective tissue cells, and intact blood vessels ${ }^{[53]}$. It was later confirmed that SVF contains a heterogeneous population of multipotent stem cells, which includes ASCs and hematopoietic stem and progenitor cells, as well as endothelial cells, pre adipocytes, and pericytes ${ }^{[53]}$. The procedure to isolate SVF and consequently, ASCs, was then successfully applied to humans ${ }^{[57]}$. Liposuction of adipose tissue was found to be the most effective way to harvest ASCs, as it produced a greater number of viable cells when compared against surgical resection ${ }^{[58]}$.

There has been an increasing trend in directly using SVFto treat wounds, instead of isolating for $\mathrm{ASCs}^{[59]}$. The ratios of cell types within SVF have been shown to be ideal for supporting capillary formation ${ }^{[59]}$. There has been, however, little consensus on the cell surface markers, including clusters of differentiation (CD), of cells within SVF, including ASCs ${ }^{[60]}$. Though combinations of positive and negative markers are proposed to discriminate ASCs from other cell types, as shown in table 1. CD34 expression, which is shared by endothelial and hematopoietic stem and progenitor cells, has been identified as a marker for ASCs ${ }^{[61,62]}$. Absence of CD31 and CD45are used to exclude endothelial and hematopoietic cell populations, respectively ${ }^{[63]}$. As such, the combination of CD31-/CD45-/CD34+ has been used to identify ASC populations in $\mathrm{SVF}^{[63,64]}$. However, there have been discrepancies in the reported percentage of 
ASCs in the treatment of chronic wounds

Table 1: Cell surface markers for adipose-derived stem cells (ASCs) and mesenchymal stem cells

\begin{tabular}{|c|c|c|}
\hline Authors & ASC Markers & MSC Markers \\
\hline Trakutec et al. ${ }^{[65]}$ & CD10+, CD13+, CD31-, CD34+, CD45-, CD90+, CD144-, & - \\
\hline Maumus et al. ${ }^{[69]}$ & $\begin{array}{l}\text { CD10+, CD13+, CD14-, CD18-, CD41-, CD49e+, CD55+, CD73+, } \\
\text { CD90+, CD166+ }\end{array}$ & $\begin{array}{l}\mathrm{CD} 10+, \mathrm{CD} 13+, \mathrm{CD} 49 \mathrm{e}+, \mathrm{CD} 55+, \mathrm{CD} 73+, \\
\mathrm{CD} 90+, \mathrm{CD} 166+\end{array}$ \\
\hline $\begin{array}{l}\text { Pachón-Peña et } \\
\text { al. }^{[62]}\end{array}$ & $\begin{array}{l}\mathrm{CD} 29+, \mathrm{CD} 34+(>30 \%), \mathrm{CD} 36+(>30 \%), \mathrm{CD} 44+, \mathrm{CD} 49 f-, \mathrm{CD} 90+, \\
\mathrm{CD} 105+, \mathrm{CD} 106-, \mathrm{CD} 166+\end{array}$ & $\begin{array}{l}\text { CD29+, CD34-, CD36-, CD44+, CD49f+, } \\
\text { CD90+, CD105+, CD106+, CD166+ }\end{array}$ \\
\hline Bourin et al. ${ }^{[64]}$ & $\begin{array}{l}\mathrm{CD} 10+, \mathrm{CD} 13+, \mathrm{CD} 29+, \mathrm{CD} 31-, \mathrm{CD} 34+\text { (unstable), CD45-, CD49+, } \\
\text { CD73+, CD90+, CD105+, CD234a-, }\end{array}$ & - \\
\hline Bianchi et al. ${ }^{[66]}$ & CD29+, CD34-, CD90+ & - \\
\hline
\end{tabular}

CD34+expressing cells ${ }^{[63,65]}$. It has been shown that expression of CD34 in ASCs is transient and decreases markedly with culture and cell expansion ${ }^{[6,67]}$. Further, method of adipose tissue harvest, digestion, isolation, and the culture medium used have an effect on CD34 expression ${ }^{[62]}$. Hence, it is maintained that positive expression of CD34 can represent ASC populations. This identification can also be used to differentiate ASCs from BMSCs, as BMSCs fail to express CD34[60]. Further, ASCs have been found to have similar cell surface markers and gene expression as mesenchymal stem cells (MSCs) ${ }^{[68,65]}$. Thereby, several alternative markers have been suggested, in addition to the ones listed, in order to better identify ASC populations. These include positive expression for the MSCs markersCD10, CD13, CD49e, CD55, CD73, CD90, and CD166. Negative expressions for hematopoietic markers CD14, CD18, and CD41 can also be considered for characterization ${ }^{[68]}$.

The exact mechanisms by which ASCs function within a wound are yet to be fully understood, however, it is widely agreed that ASCs release cytokines and growth factors that promote wound healing ${ }^{[69]}$. Studies have examined and compared the microenvironments of acute and chronic wounds in order to better understand how they affect ASCs.Acute wound fluid (AWF) is a rich source of cytokines and growth factors that has been shown to stimulate the growth and proliferation of dermal fibroblasts, endothelial cells, and ASCs in vitro, thereby, positively improving the wound healing outcome ${ }^{[70,71]}$. In contrast, chronic wound fluid (CWF) has been shown to impair the proliferation and migration rate of $\mathrm{ASCs}^{[72]}$. The inverse effect of AWF and CWF on cell function has been attributed to the protease microenvironment of chronic wounds. The abundance of inflammatory cytokines results in elevated levels of matrix metalloproteinases (MMPs) through processes that both stimulate their production and inhibit their degradation ${ }^{[73,74]}$. As such, the concentration of MMPs in CWF have been shown to reflect the severity of a chronic ulcer ${ }^{[75]}$. MMPs are also found in AWF and are required for normal wound healing ${ }^{[76]}$. It regulates various aspects of inflammation, re-epithelialization, and degradation of the extracellular matrix for remodelling during wound healing ${ }^{[76]}$. Though, when MMP's are present in large concentrations, as they are in CWF, their effect on wound healing becomes detrimental ${ }^{[77]}$. Therefore, the microenvironments found in AWF and CWF are largely responsible for the differences in wound healing and can significantly affect the efficacy of ASCs in the wound.

\section{ASCs, pressure and venous ulcers}

To date, very few studies have used ASCs in the context of treating pressure or venous ulcers, mainly due to the lack of appropriate animal models ${ }^{[78]}$. In response, a model of pressure ulcers in rodents was created by Stadler et $\mathrm{a}^{[79]}$ by compressing the dorsal skin between two magnets. The magnets mimic ischemia-reperfusion cycles by compressing the skin for three cycles of 12 hours, with each cycle followed by 12 hours of rest. A recent study by Strong et $\mathrm{al}^{[80]}$ applied this model of pressure ulcers in mice and examined the effect of injected allogeneic ASCs in wound healing. Histomorphological analysis showed that ASC treated mice had enhanced wound healing outcomes due to reduced epidermal hypertrophy and increased thickness of dermis, subcutaneous, and muscle layers. Given the promising result, more research must go into examining ASCs as treatment for these types of chronic wounds.

\section{ASCs and diabetic chronic wounds}

Diabetes poses a complex challenge to wound healing as over 100 physiological factors contribute to the impairment of wound healing processing individuals with diabetes ${ }^{[81]}$. These include a reduction or impairment in growth factor production, collagen accumulation, angiogenic responses, quantity of granulation tissue, and keratinocyte and fibroblast proliferation and migration. Numerous studies have examined the application of ASCs within full thickness diabetic wound models and have investigated how ASCs improvewound healing outcomes. Studies have found that diabetic wounds treated witha local injection of allogeneic ASCs from a non-diabetic donor had improved wound healing outcomes, similar to that of untreated non-diabetic wounds ${ }^{[82,83]}$. Both of which, had significantly faster wound healing rates than untreated diabetic wounds. It was suggested that ASCs might be enhancing the wound healing rate by means other than angiogenesis or accumulation of collagen fibers, since no significant difference in volume density of collagen fibers or length and volume densityof vessels between the ASC treatment groups and control were found ${ }^{[82]}$. However, the results of many other studies suggest otherwise and support the notion that ASCs release growth factors that enhance angiogenesis. For instance, Nie et al ${ }^{[83]}$ demonstrated in vitro that ASC treated wounds had higher expression of vascular endothelial growth factor (VEGF), hepatocyte growth factor (HGF), and fibroblast growth factor 2 (FGF2) than controls, therefore, promoting angiogenesis, cell proliferation and migration ${ }^{[84-86]}$. In vivo analysis by the same group supported these results and found that a local injection of autologous ASCs significantly increased epithelialization, blood vessel density, granulation tissue, and reduced wound closure time in full thickness wounds in both diabetic and non-diabetic rat models when compared against controls ${ }^{[83]}$. A study by Zo- 
grafou et $\mathrm{al}^{[87]}$ examined the use of autologous ASCs with full thickness skin grafts in a diabetic rat model. ASCs enhanced skin graft survivaland resulted in greater collagen density, expression of transforming growth factor $\beta$ (TGF- $\beta$ ), and VEGF, which promoted greater cell proliferation and angiogenesis. Thus, the results of these studies demonstrate the capability of ASCs to release growth factors thatsignificantly improve the wound healing outcome of diabetic wounds, thereby, supporting their use for treatment.

Given the numerous physiological factors that impair wound healing in individuals with diabetes, researchers have examined whether ASCs that are obtained from diabetic donors improve wound healing to the same degree as ASCs from non-diabetic donors. Using a diabetic mouse model, Cianfarani et al ${ }^{[88]}$ compared the efficacy of autologous and allogeneic ASCs from diabetic and non-diabetic donors, respectively. They demonstrated that diabetic wounds treated with allogeneic non-diabetic ASCs had significantly improved wound healing outcomes when compared to diabetic wounds treated with autologous diabetic ASCs or untreated wounds. Histological and computer assisted morphometric analysis showed that non-diabetic ASCs resulted in significantly higher granulation tissue extension, collagen deposition, and vessel density in diabetic wounds than diabetic ASCs ${ }^{[88]}$. Further, in vitro analysis demonstrated that ASCs from non-diabetic donors had greater proliferation, and significantly higher concentrations of VEGF-A, HGF, and insulin growth factor - 1 (IGF-1) than ASCs obtained from diabetic donors. Within the same study, it was also found that the source of ASCs affected other cells within media. Boyden chamber assays revealed that keratinocytes and fibroblasts cultured in medium conditioned with non-diabetic ASCs had improved migration and proliferation ability, with respect to cells cultured in diabetic ASCs cell-conditioned media. Hence, allogeneic ASCs from non-diabetic donors have improved function and greater wound healing outcomes than ASCs from diabetic donors. As such, this study demonstrates the potential for allogeneic ASC based therapy.

\section{Application of ASCs using three-dimensional scaffolds}

Cell sheets have been examined as an alternative way to use ASCs in full thickness wounds other than local injections. It has been demonstrated that ASCs which are applied to the wound in the form of cell sheets have improved wound healing outcomes ${ }^{[89,90]}$. The cell sheets are created by culturing the cell for an extended period of time, which creates a sheet-like tissue that can be used for tissue reconstruction ${ }^{[91]}$. In particular, thicker triple layered ASC sheets have shown to result in greater collagen density than single layered sheets. Another study compared two different methods of producing cell sheets and found that triple layered ASCs obtained from thermoresponsive surfaces promoted a thicker epidermal surface than cell sheets obtained from standard cell culture surfaces ${ }^{[92]}$. Despite the improvement in wound healing as a result of thicker cell sheets, no significant differences in angiogenesis were found between the triple and single layered cell sheets from either method of production ${ }^{[89-92]}$.

Several studies have also examined seeding ASCs with skin substitutes to improve its clinical use. Skin substitutes are epidermal, dermal, or bilayered bioengineered three-dimensional matrixes with variable cellular content and structure. It serves as a backbone for cell infiltration into the wound bed that is followed by neovascularization and tissue regeneration ${ }^{[33,94]}$. Hence, it promotes wound repair by enhancing the migration of cells, such as, fibroblasts, keratinocytes, and endothelial, cells into the wound. However, one limiting factor of scaffolds and other types of skin substitutes have been its low regenerative factor, which is mainly a result of the poor vascularization capacity of these scaffolds ${ }^{[93]}$. This results in a reduction inoxygen, nutrients, and immune cells that reach the wound. Consequently, attention has turned to seeding skin substitutes with ASCs to improve vascularization and promote angiogenesis within the wound.A study by Kato et $\mathrm{a}^{\left[{ }^{[95]}\right.}$ examined the combination of artificial skin and allogeneic ASC cell sheets to treat a full thickness wound in a diabetic rat model. The combination of a skin substitute with ASC sheets increased vessel density and reduced wound area and closure time in comparison to artificial skin or ASC treatment alone ${ }^{[88]}$ Jiang et al ${ }^{[96]}$ found that the combination of collagen scaffolds and autologous ASC sheets resulted in higher vascularization and expression of VEGF and basic fibroblast growth factor (bFGF), when compared to ASC sheets alone or topically applied ASCs. Thus, the combination of three-dimensional scaffolds with ASC cell sheets significantly promotes wound healing by reducing wound closure rate and by enhancing angiogenesis, cell migration and proliferation.

Other studies have examined seeding scaffolds with $\mathrm{ASCs}^{[97,98]}$. It was demonstrated that acellular dermal matrices (ADMs) seeded with human ASCs significantly increased the amount of blood vessels and reduced wound closure rate in nude mice when compared against controls ${ }^{[99]}$. Though no difference in granulation tissue was found as a result of the ADM-ASC groups. Results from another study have also shown that seeding two different types of extracellular matrix scaffolds, small intestinal submucosa or ADM, with ASCs resulted in greater microvessel density, proliferation rate, and wound healing rate than ASC seeded composite scaffolds ${ }^{[100]}$. As a conclusion, the combination of skin substitutes and ASCs have extensively improved the wound healing outcomes in vivo and should be considered for clinical treatment in comparison to topical administration or injection of ASCs into the wound site.

\section{Application of ASCs in clinical trials}

The promising use of ASCs as a treatment for wounds has also been investigated in clinical trials, though not extensively. The use of ASCs have been successful in the treatment of other wound types, such as chronic radiation ulcers or non-revascularizable critical limb Ischemia ${ }^{[101,102]}$. Few studies, however, have examined the clinical use of ASCs in chronic wounds. In one study of venous ulcers, Salemi et $\mathrm{al}^{[101]}$ found that applying autologous ASCs in a platelet rich plasma to the wound improved its healing outcome in an individual with lower leg ulcers. Another study by Marino et $\mathrm{a}^{[103]}$ treated the chronic ulcers of ten diabeticpatients with peripheral arterial disease with a local intradermal injection of allogeneic ASCs from non-diabetic donors. The chronic ulcers of six out of the treated 10 patients healed successfully. Given the results of these studies, ASCs has demonstrated high potential in the treatment of chronic wounds and it's clinical use must be investigated further. A summary of studies on the application of ASCs for treatment of chronic wounds in experimental models and clinical trials are provided in Table 2. 
Table 2: Summary of investigation on the application of ASCs in treatment of chronic wounds

\begin{tabular}{|c|c|c|c|c|}
\hline Author & $\begin{array}{l}\text { Chronic Wound } \\
\text { Model }\end{array}$ & $\begin{array}{l}\text { Subject } \\
\text { Group }\end{array}$ & ASC Application & Healing Outcome \\
\hline Cerqueira et al. ${ }^{[94]}$ & Diabetic ulcer & Mouse & $\begin{array}{l}\text { ASC seeded cell } \\
\text { sheets }\end{array}$ & $\begin{array}{l}\text { ASCs cell sheets from thermoresponsive surfaces promoted a thicker } \\
\text { epidemeral surface vs. cell sheets from standard cell culture surfaces }\end{array}$ \\
\hline Cianfarani et al. ${ }^{[90]}$ & Diabetic ulcer & Mouse & Injected ASCs & $\begin{array}{l}\text { Diabetic mice treated with non-diabetic allogeneic ASC had in- } \\
\text { creased granulation tissue extension, collagen deposition, and vessel } \\
\text { density }\end{array}$ \\
\hline Huang et al. ${ }^{[99]}$ & Diabetic ulcer & $\begin{array}{l}\text { Nude } \\
\text { Mouse }\end{array}$ & $\begin{array}{l}\text { ASC seeded acellu- } \\
\text { lar dermal matrix }\end{array}$ & $\begin{array}{l}\text { ASC- ADM increased angiogenesis and wound closure rate but did } \\
\text { not increase granulation tissue vs. acellular dermal matrix or ASC } \\
\text { treatment alone. }\end{array}$ \\
\hline Jiang et al. ${ }^{[98]}$ & Diabetic ulcer & Pig & $\begin{array}{l}\text { Collagen } \quad \text { scaffold } \\
\text { with ASC cell sheets }\end{array}$ & $\begin{array}{l}\text { Combination of scaffold and ASC cell sheets increased vasculariza- } \\
\text { tion and expression of VEGF and bFGF vs. cell sheets alone or top- } \\
\text { ically applied ASCs }\end{array}$ \\
\hline Kato et al. ${ }^{[97]}$ & Diabetic ulcer & Rat & $\begin{array}{l}\text { Artificial skin with } \\
\text { ASC seeded cell } \\
\text { sheets }\end{array}$ & $\begin{array}{l}\text { Combination of the two treatments increased vessel density and } \\
\text { wound closure rate vs. artificial skin or ASC cell sheet treatment } \\
\text { alone }\end{array}$ \\
\hline Kim et al. ${ }^{[84]}$ & Diabetic ulcer & $\begin{array}{l}\text { Nude } \\
\text { Mouse }\end{array}$ & Injected ASCs & $\begin{array}{l}\text { Diabetic wounds treated with non-diabetic allogeneic ASCs healed } \\
\text { similarly to untreated non-diabetic wounds }\end{array}$ \\
\hline Lin et al. ${ }^{[91]}$ & Diabetic ulcer & $\begin{array}{l}\text { Nude } \\
\text { Mouse }\end{array}$ & $\begin{array}{l}\text { ASC seeded cell } \\
\text { sheets }\end{array}$ & $\begin{array}{l}\text { Triple- layered ASC seeded cell sheets increased wound healing rate } \\
\text { vs. single layer sheets; no difference in vessel density or gene expres- } \\
\text { sion between two groups }\end{array}$ \\
\hline Liu et al. ${ }^{[100]}$ & Diabetic ulcer & Mouse & $\begin{array}{l}\text { ASC seeded small } \\
\text { intestinal submuco- } \\
\text { sa scaffold vs. accel- } \\
\text { lular dermal matrix }\end{array}$ & $\begin{array}{l}\text { ASCs seeded scaffolds increased microvessel density, proliferation } \\
\text { rate, and wound closure rate vs. collagen scaffold; no difference } \\
\text { found between the two types of scaffolds examined }\end{array}$ \\
\hline $\begin{array}{l}\text { Maharlooei et } \\
\text { al. }{ }^{[83]}\end{array}$ & Diabetic ulcer & Rat & Injected ASCs & Reduced wound closure rate; no evidence of angiogenesis \\
\hline Marino et al. ${ }^{[103]}$ & $\begin{array}{l}\text { Lower leg chron- } \\
\text { ic ulcer }\end{array}$ & $\begin{array}{l}\text { Clinical } \\
\text { trial }\end{array}$ & Injected ASCs & Wounds of six of ten patients healed successfully \\
\hline $\begin{array}{l}\text { McLaughlin et } \\
\text { al. }{ }^{[92]}\end{array}$ & Diabetic ulcer & $\begin{array}{l}\text { Nude } \\
\text { Mouse }\end{array}$ & $\begin{array}{l}\text { ASC seeded cell } \\
\text { sheets }\end{array}$ & $\begin{array}{l}\text { Triple- layered ASC seeded cell sheets increased wound healing vs. } \\
\text { single layered sheets }\end{array}$ \\
\hline Nie et al. & Diabetic ulcer & Rat & Injected ASCs & $\begin{array}{l}\text { Increased epithelialization, blood vessel density, granulation tissue } \\
\text { and accelerated wound closure rate. Higher expression of VEGF, } \\
\text { HGF, and FGF2 in vitro }\end{array}$ \\
\hline Salemi et al. ${ }^{[103]}$ & $\begin{array}{l}\text { Lower leg chron- } \\
\text { ic skin ulcer }\end{array}$ & $\begin{array}{l}\text { Clinical } \\
\text { trial }\end{array}$ & $\begin{array}{l}\text { ASCs mixed with } \\
\text { platelet rich plasma }\end{array}$ & Improved wound healing outcome \\
\hline Zografou et al. ${ }^{[89]}$ & Diabetic ulcer & Rat & Injected ASCs & Increased collagen density and expression of TGF- $\beta$ and VEGF \\
\hline
\end{tabular}

\section{Conclusion}

Several studies have shown the potential of ASCs in treating chronic wounds in both in vivo and in vitro studies. The ability to promote epithelization, angiogenesis, cell migration and proliferation, and secrete growth factors have been noted in the majority of these studies. Further, seeding skin substitutes with ASCs have been shown to result in greater healing than directly injecting or applying cell sheets to the wound. As all studies have resulted in improved healing in ASC treated wounds, the use of ASCs to treat chronic wounds has been promising and clinical treatment must be investigated further.

\section{References}

1. Lazarus, G.S., Cooper, D.M., Knighton, D.R., et al. Definitions and guidelines for assessment of wounds and evaluation of healing. (1994) Arch Dermatol 130(4): 489-493.

2. Eaglstein, W.H., Falanga, V. Chronic wounds. (1997) Surg Clin North Am 77(3): 689-700.

3. Graham, I.D., Harrison, M.B., Shafey, M., et al. Knowledge and attitudes regarding care of leg ulcers. (2003) Can Fam Physician 49(7): 896-902.

4. Hurd, T., Zuiliani, N., Posnett, J. Evaluation of the impact of restructuring wound management practices in a community care provider in Niagara, Canada. (2008) Int Wound J 5(2): 296-304.

5. Woodbury, G.M., Houghton, P.E. Prevalence of pressure ulcers in Canadian healthcare settings. (2004) Ostomy Wound Manage 50(10): 22-38. 6. Health Quality Ontario. Community-based care for chronic wound management: an evidence-based analysis. (2009) Ont Health Technol Assess Ser 9(18): 1-24. 
7. Sommerville, R. Economic Tsunami: The cost of diabetes in Canada. (2009) Canadian Diabetes Association.

8. Singh, N., Armstrong, D.G., Lipsky, B.A. Preventing Foot Ulcers in Patients with Diabetes. (2005) J Am Med Assoc 293(2): 217-228.

9. Guo, S., Dipietro, L.A. Factors affecting wound healing. (2010) J Dent Res 89(3): 219-229.

10. Driver, V.R., Fabbi, M., Lavery, L.A., et al. The costs of diabetic foot: the economic case for the limb salvage team. (2010) J Vasc Surg 52(3 Suppl): 17S-22S.

11. White-Chu, E.F., Flock, P., Struck, B., et al. Pressure ulcers in longterm care. (2011) Clin Geriatr Med 27(2): 241-258.

12. Lazarus, G., Valle, M.F., Malas, M., et al. Chronic venous leg ulcer treatment: future research needs. (2014) Wound Repair Regen 22(1): 34-42.

13. Reddy, M., Gill, S.S., Kalkar, S.R., et al. Treatment of pressure ulcers: a systematic review. (2008) JAMA 300(22): 2647-2662.

14. Zuk, P.A., Zhu, M.I.N., Mizuno, H., et al. Multilineage Cells from human adipose tissue: implications for cell-based therapies. (2001) Tissue Eng 7(2): 211-228.

15. Bennett, N.T., Schultz, G.S. Growth factors and wound healing: part II. role in normal and chronic wound healing. (1993) Am J Surg 166(1):74-81.

16. Witte, M.B., Barbul, A. General principles of wound healing. (1997) Surg Clin North Am 77(3): 509-528.

17. Martin, P. Perfect aiming healing for skin regeneration. (1997) Science 276(5309): 75-81.

18. Broughton, G., Janis, J.E., Attinger, C.E. The basic science of wound healing. (2006) Plast Reconstr Surg 117(7 Suppl):12S-34S.

19. Velnar, T., Bailey, T., Smrkolj, V. The wound healing process: an overview of the cellular and molecular mechanisms. (2015) J Int Med Res 37(5):1528-1542.

20. Steenfos, H.H. Growth factors and wound healing. (1994) Scand J Plast Reconstr Surg Hand Surg 28(2): 95-105.

21. Tonnesen, M.G., Feng, X., Clark, R.A.F. Angiogenesis in wound healing. (2000) J Investig Dermatol Symp Proc 5(1): 40-46.

22. Bjarnsholt, T., Kirketerp-Møller, K., Jensen, P.Ø., et al. (2008) Wound Repair Regen 16(1): 2-10.

23. Brem, H., Stojadinovic, O., Diegelmann, R.F., et al. Molecular markers in patients with chronic wounds guide to surgical debridement. (2007) Mol Med Cambridge Mass 13(1-2): 30-39.

24. Menke, N.B., Ward, K.R., Witten, T.M., et al. Impaired wound healing. (2007) Clin Dermatol 25(1):19-25.

25. Bennett, S.P., Griffiths, G.D., Schor, A.M., et al. Growth factors in the treatment of diabetic foot ulcers. (2003) Br J Surg 90(2):133-146.

26. Robson, M.C., Cooper, D.M., Aslam, R., et al. Guidelines for the treatment of venous ulcers. (2006) Wound Repair Regen 14(6): 649662.

27. Chen, S.M., Ward, S.I., Olutoye, O.O., et al. Ability of chronic wound fluids to degrade peptide growth factors is associated with increased levels of elastase activity and diminished levels of proteinase inhibitors. (1997) Wound Repair Regen 5(1): 23-32.

28. Wysocki, A.B., Staiano-Coico, L., Grinnell, F. Wound fluid from chronic leg ulcers contains elevated levels of metalloproteinases MMP2 and MMP-9. (1993) J Invest Dermatol 101(1): 64-68.

29. Abbade, L.P.F., Lastória, S. Venous ulcer: epidemiology, physiopathology, diagnosis and treatment. (2005) Int J Dermatol 44(6): 449-456. 30. Pittenger, M.F., Mackay, A.M., Beck, S.C., et al. Multilineage potential of adult human mesenchymal stem cells. (1999) Science 284(5411):143-147.

31. Bunnell, B.A., Flaat, M., Gagliardi, C., et al. Adipose-derived stem cells: isolation, expansion and differentiation. (2008) Methods 45(2): 115-120.

32. Gimble, J.M. Adipose tissue-derived therapeutics. (2003) Expert Opin Biol Ther 3(5): 705-713.

33. Jiang, Y., Jahagirdar, B.N., Reinhardt, R.L., et al. Pluripotency of mesenchymal stem cells derived from adult marrow. (2002) Nature 418(6893): 41-49.
34. Wagner, W., Wein. F., Seckinger, A., et al. Comparative characteristics of mesenchymal stem cells from human bone marrow, adipose tissue, and umbilical cord blood. (2005) Exp Hematol 33(11):1402-1416. 35. Badiavas, E.V., Falanga,V. Treatment of chronic wounds with bone marrow-derived cells. (2003) Arch Dermatol 139(4): 510-516.

36. Nakagawa, H., Akita, S., Fukui, M., et al. Human mesenchymal stem cells successfully improve skin-substitute wound healing. (2005) Br J Dermatol 153(1): 29-36.

37. Falanga, V., Iwamoto, S., Chartier, M., et al. Autologous bone marrow-derived cultured mesenchymal stem cells delivered in a fibrin spray accelerate healing in murine and human cutaneous wounds. (2007) Tissue Eng 13(6): 1299-1312.

38. Zhu, Y., Liu,T., Kedong, S., et al. Adipose-derived stem cell: a better stem cell than BMSC. (2008) Cell Biochem Funct 26(7): 664-675.

39. Makhluf, H.A., Mueller, S.M., Shuichi, M., et al. Age-related decline in osteoprotegerin expression by human bone marrow cells cultured in three-dimensional collagen sponges. (2000) Biochem Biophys Res Commun 268(3): 669-672.

40. D'Ippolito, G., Schiller, P.C., Ricordi, C., et al. Age-related osteogenic potential of mesenchymal stromal stem cells from human vertebral bone marrow. (1999) J Bone Miner Res 14(7): 1115-1122.

41. Muschler, G.F., Nitto, H., Boehm, C.A., et al. Age and gender-related changes in the cellularity of human bone marrow and the prevalence of osteoblastic progenitors. (2001) J Orthop Res 19(1): 117-125.

42. Banfi, A., Bianchi, G., Galotto, M., et al. Bone marrow stromal damage after chemo/radiotherapy: occurrence, consequences and possibilities of treatment. (2001) Leuk Lymphoma 42(5): 863-870.

43. Erickson, G.R., Gimble, J.M., Franklin, D.M., et al. Chondrogenic potential of adipose tissue-derived stromal cells in vitro and in vivo. (2002) Biochem Biophys Res Commun 290(2): 763-769.

44. Zuk, P.A., Zhu, M., Ashjian, P., et al. Human adipose tissue is a source of multipotent stem cells. (2002) Mol Biol Cell 13(12): 42794295.

45. Miranville, A., Heeschen, C., Sengenès, C., et al. Improvement of postnatal neovascularization by human adipose tissue-derived stem cells. (2004) Circulation 110(3): 349-355.

46. Planat-Benard, V., Silvestre, J.S., Cousin, B., et al. Plasticity of human adipose lineage cells toward endothelial cells: physiological and therapeutic perspectives. (2004) Circulation 109(5): 656-663.

47. Safford, K.M., Hicok, K.C., Safford, D., et al. Neurogenic differentiation of murine and human adipose-derived stromal cells. (2002) Biochem Biophys Res Commun 294(2): 371-379.

48. Strem, B.M., Hicok, K.C., Zhu, M., et al. Multipotential differentiation of adipose tissue-derived stem cells. (2005) Keio J Med 54(3): 132-141.

49. Puissant, B., Barreau, C., Bourin, P., et al. Immunomodulatory effect of human adipose tissue-derived adult stem cells: comparison with bone marrow mesenchymal stem cells. (2005) Br J Haematol 129(1): $118-129$

50. Strem, B.M., Hedrick, M.H. The growing importance of fat in regenerative medicine. (2005) Trends Biotechnol 23(2): 64-66.

51. Cowan, C.M., Shi. Y.Y., Aalami, O.O., et al. Adipose-derived adult stromal cells heal critical-size mouse calvarial defects. (2004) Nat Biotechnol 22(5): 560-570.

52. Hong, S.J., Jia, S.X., Xie, P., et al. Topically delivered adipose derived stem cells show an activated-fibroblast phenotype and enhance granulation tissue formation in skin wounds. (2013) PLoS One 8(1): e55640.

53. Rodbell, M. Metabolism of isolated fat cells 1. Effects of hormones on glucose metabolism and lipolysis . (1964) Dis Metab 239(2): 375380.

54. Rodbell, M. Metabolism of isolated fat cells 2. The similar effects of phospholipase C (Clostriudium perfringens alpha toxin) and of insulin on glucose and amino acid metabolism. (1966) J Biol Chem 241(1): $130-139$. 
55. Rodbell, M., Jones, A.B. Metabolism of isolated fat cells 3. The similar inhibitory action of phospholipase c (Clostridium perfringens alpha toxin) and of insulin on lipolysis stimulated by lipolytic hormones and theophylline. (1966) J Biol Chem 241(1): 140-142.

56. Zimmerlin, L., Donnenberg, V.S., Pfeifer, M.E., et al. Stromal vascular progenitors in adult human adipose tissue. (2009) Cytom Part A 77A(1): 22-30.

57. Van, R.L.R., Bayliss, C.E., Roncari, D.A.K. Cytological and enzymological characterization of adult human adipocyte precursors in culture. (1976) J Clin Invest 58(3): 699-704.

58. Schreml, S., Babilas, P., Fruth, S., et al. Harvesting human adipose tissue-derived adult stem cells: resection versus liposuction. (2009) Cytotherapy 11(7): 947-957.

59. Klar, A.S., Güven, S., Biedermann, T., et al. Tissue-engineered dermo-epidermal skin grafts prevascularized with adipose-derived cells. (2014) Biomaterials 35(19): 5065-5078.

60. Guo, J., Nguyen, A., Banyard, D.A., et al. Stromal vascular fraction: a regenerative reality? Part 2: mechanisms of regenerative action. (2015) J Plast Reconstr Aesthet Surg 1-9.

61. Pachón-Peña, G., Yu, G., Tucker, A., et al. Stromal stem cells from adipose tissue and bone marrow of age-matched female donors display distinct immunophenotypic profiles. (2011) J Cell Physiol 226(3): 843-851.

62. Sengenès, C., Lolmède, K., Zakaroff, G.A., et al. Preadipocytes in the human subcutaneous adipose tissue display distinct features from the adult mesenchymal and hematopoietic stem cells. (2005) J Cell Physiol 205(1):114-122.

63. Bourin, P., Bunnel,1 B.A., Casteilla, L., et al. Stromal cells from the adipose tissue-derived stromal vascular fraction and culture expanded adipose tissue-derived stromal/stem cells: a joint statement of the International Federation for Adipose Therapeutics and Science (IFATS) and the International Society for Cellular Therapy (ISCT). (2013) Cytotherapy 15(6): 641-648.

64. Traktuev, D.O., Merfeld, C.S., Li, J., et al. A population of multipotent CD34-positive adipose stromal cells share pericyte and mesenchymal surface markers, resides in a periendothelial location, and stabilize endothelial networks. (2008) Cell Biol 102(1): 77-85.

65. Bianchi, F., Maioli, M., Leonardi, E., et al. A new nonenzymatic method and device to obtain a fat tissue derivative highly enriched in pericyte-like elements by mild mechanical forces from human lipoaspirates. (2013) Cell Transplant 22(11): 2063-2077.

66. Rehman, J., Traktuev, D., Li, J., et al. Secretion of angiogenic and antiapoptotic factors by human adipose stromal cells. (2004) Circulation 109(10): 1292-1298.

67. Yu, G., Wu, X., Dietrich, M.A., et al. Yield and characterization of subcutaneous human adipose-derived stem cells by flow cytometric and adipogenic mRNA analyzes. (2010) Cytotherapy 12(4): 538-546.

68. Maumus, M., Peyrafittem, J.A., D’Angelo, R., et al. Native human adipose stromal cells: Localization, morphology and phenotype. (2011) Int J Obes 35(9): 1141-1153.

69. Gimble, J.M., Katz, A.J., Bunnell, B.A. Adipose-derived stem cells for regenerative medicine. (2007) Circ Res 100(9): 1249-60.

70. Katz, M.H., Alvarez, A.F., Kirsner, R.S., et al. Human wound fluid from acute wounds stimulates fibroblast and endothelial cell growth. (1991) J Am Acad Dermatol 25(6): 1054-1058.

71. Scherzed, A., Hackenberg, S., Froelich, K., et al. The effect of wound fluid on adipose-derived stem cells in vitro: a study in human cell materials. (2011) Tissue engineering Part C Methods 17(8): 809817.

72. Koenen, P., Spanholtz, T.A., Maegele, M., et al. Acute and chronic wound fluids inversely influence adipose-derived stem cell function: molecular insights into impaired wound healing. (2015) Int Wound J 12(1): 10-6.

73. Ito, A., Sato, T., Iga, T., et al. Tumor necrosis factor bifunctionally regulates matrix metalloproteinases and tissue inhibitor of metalloproteinases (TIMP) production by human fibroblasts. (1990) FEBS Lett
269(1): 93-5.

74. Trengrove, N.J., Stacey, M.C., Macauley, S., et al. Analysis of the acute and chronic wound environments: the role of proteases and their inhibitors. (1999) Wound Repair Regen 7(6): 442-452.

75. Rayment, E.A., Upton, Z., Shooter, G.K. Increased matrix metalloproteinase-9 (MMP-9) activity observed in chronic wound fluid is related to the clinical severity of the ulcer. (2008) Br J Dermatol 158(5): 951-961.

76. Gill, S.E., Parks, W.C. Metalloproteinases and their inhibitors: regulators of wound healing. (2008) Int J Biochem Cell Biol 40(6-7): 1334-1347.

77. Liu, Y., Min, D., Bolton, T., et al. Increased matrix metalloproteinase-9 predicts poor wound healing in diabetic. (2009) Diabetes Care 32(1): 117-119.

78. Mustoe, T. Understanding chronic wounds: a unifying hypothesis on their pathogenesis and implications for therapy. (2004) Am J Surg 187(5 SUPPL.1): 65S-70S.

79. Stadler, I., Zhang, R.Y., Oskoui, P., et al. Development of a simple, noninvasive, clinically relevant model of pressure ulcers in the mouse. (2004) J Invest Surg 17(4): 221-227.

80. Strong, A.L., Bowles, A.C., MacCrimmon, C.P., et al. Adipose stromal cells repair pressure ulcers in both young and elderly mice: potential role of adipogenesis in skin repair. (2015) Stem Cells Transl Med 4(6): $1-10$.

81. Brem, H., Tomic, C.M. Cellular and molecular basis of wound healing in diabetes. (2007) J Clin Invest. 117(5): 1219-1222.

82. Maharlooei, M.K., Bagheri, M., Solhjou, Z., et al. Adipose tissue derived mesenchymal stem cell (AD-MSC) promotes skin wound healing in diabetic rats. (2011)Diabetes Res Clin Pract 93(2): 228-234.

83. Kim, E.K., Li, G., Lee, T.J., et al. The effect of human adipose-derived stem cells on healing of ischemic wounds in a diabetic nude mouse model. (2011) Plast Reconstr Surg 128(2): 387-394.

84. Nie, C., Yang, D., Xu, J., et al. Locally administered adipose-derived stem cells accelerate wound healing through differentiation and vasculogenesis. (2011) Cell Transplant 20(2): 205-216.

85. Lawrence, T.W., Diegelmann, R.F. Growth factors in wound healing. (1994) Clin Dermatol 21(1): 157-169.

86. Bao, P., Kodra, A., Tomic-Canic, M., et al. The Role of vascular endothelial growth factor in wound healing. (2009) J Surg Res. 153(2): 347-358.

87. Conway, K.P., Price, P.E., Harding, K.G., et al. The molecular and clinical impact of hepatocyte growth factor, its receptor, activators, and inhibitors in wound healing. (2006) Wound repair Regen 14(1): 2-10. 88. Zografou, A., Papadopoulos, O., Tsigris, C., et al. Autologous transplantation of adipose-derived stem cells enhances skin graft survival and wound healing in diabetic rats. (2013) Ann Plast Surg 71(2): 225232.

89. Cianfarani, F., Toietta, G., Di Rocco, G., et al. Diabetes impairs adipose tissue-derived stem cell function and efficiency in promoting wound healing. (2013) Wound Repair Regen 21(4): 545-553.

90. Lin, Y.C., Grahovac, T., Oh, S.J., et al. Evaluation of a multi-layer adipose-derived stem cell sheet in a full-thickness wound healing model. (2013) Acta Biomater 9(2): 5243-5250.

91. McLaughlin, M.M., Marra, K.G. The use of adipose-derived stem cells as sheets for wound healing. Organogenesis (2013) 9(2): 79-81.

92. Yang, J., Yamato, M., Shimizu, T., et al. Reconstruction of functional tissues with cell sheet engineering. (2007) Biomaterials 28(34): 5033-5043.

93. Cerqueira, M.T., Pirraco, R.P., Santos, T.C., et al. Human adipose stem cells cell sheet constructs impact over the epidermal regeneration of full-thickness excisional wounds. (2013) Biomacromolecules 14(11): 3997-4008.

94. Egaña, J.T., Fierro, F.A., Krüger, S., et al. Use of human mesenchymal cells to improve vascularization in a mouse model for scaffold-based dermal regeneration. (2009) Tissue Eng Part A 15(5): 11911200 . 
95. Greaves, N.S., Iqbal, S.A., Baguneid, M., et al. The role of skin substitutes in the management of chronic cutaneous wounds. (2013) Wound Repair Regen 21(2): 194-210.

96. Kato, Y., Iwata, T., Morikawa, S., et al Allogeneic transplantation of an adipose-derived stem cell (ASC) sheet combined with artificial skin accelerates wound healing in a rat wound model of type 2 diabetes and obesity. (2013) Am Diabetes Assoc (81): 1-46.

97. Jiang, Y., Chen, B., Liu, Y., et al. Effect of collagen scaffold with adipose-derived stromal vascular fraction cells on diabetic wound healing: a study in a diabetic porcine model. (2013) Tissue Eng Regen Med 10(4): 192-199.

98. Huang ,S.P., Hsu, C.C., Chang, S.C., et al. Adipose-derived stem cells seeded on acellular dermal matrix grafts enhance wound healing in a murine model of a full-thickness defect. (2012) Ann Plast Surg 69(6): 656-662.

99. Liu, S., Zhang, H., Zhang, X., et al. Synergistic angiogenesis promoting effects of extracellular matrix scaffolds and adipose-derived stem cells during wound repair. (2011)Tissue engineering Part A 17(56): 725-739.
100. Akita, S., Yoshimoto, H., Ohtsuru, A., et al. Autologous adipose-derived regenerative cells are effective for chronic intractable radiation injuries. (2012) Radiat Prot Dosimetry 151(4): 656-660.

101. Bura, A., Planat-Benard, V., Bourin, P., et al. Phase I trial: the use of autologous cultured adipose-derived stroma/stem cells to treat patients with non-revascularizable critical limb ischemia. (2014) Cytotherapy 16(2): 245-257.

102. Salemi, S., Rinaldi, C., Manna, F., et al. Reconstruction of lower leg skin ulcer with autologous adipose tissue and platelet-rich plasma. (2008) J Plast Reconstr Aesthetic Surg 61(12): 1565-1567.

103. Marino, G., Moraci, M., Armenia, E., et al. Therapy with autologous adipose-derived regenerative cells for the care of chronic ulcer of lower limbs in patients with peripheral arterial disease. (2013) J Surg Res 185(1): 36-44.
Online ISSN: 2381-0858

Journal Title: Investigative Dermatology and Venereology Research Journal Short Name: Invest Dermatol Venereol Res
Ommega Online Publishers

E-mail: editor.dermatology@ommegaonline.org Website: www.ommegaonline.org 